\title{
MUTUAL AID IN SOCIAL REINTEGRATION OF FORMER TERRORIST PRISONER IN INDONESIA
}

\author{
SAIFUDIN ASRORI, AHMAD SYAUQI \\ Syarif Hidayatullah State Islamic University Jakarta, Indonesia \\ Email: saifudin.asrori@uinjkt.ac.id
}

\begin{abstract}
The involvement of former terrorist prisoners in social and economic empowerment efforts, especially members or ex-convicts who disengage the terrorist groups is an interesting and unique phenomenon. This article aims to explore the empowerment of ex-terrorist convicted on de-radicalization and social reintegration disengaging terrorist back into society. Through interviews of several activists ex-Jihadist and observation of empowerment programs, this article conclude that the former terrorist prisoner's engagement in the empowerment initiatives as an alternate of government deradicalization programs of former terrorist prisoner. This group became the 'new community' for ex-extremists to express various views and believe without concealment. The presence of this group is a potential asset in promoting narratives against radicalism and terrorism in Indonesia.
\end{abstract}

Keywords: Reintegration; Jihadists, Economic Development; Indonesia.

\begin{abstract}
Abstraks. Pelibatan mantan narapidana teroris dalam upaya pemberdayaan sosial dan ekonomi, khususnya anggota atau mantan narapidana yang memisahkan diri dari kelompok teroris merupakan fenomena yang menarik dan unik. Artikel ini bertujuan mengeksplorasi pemberdayaan eks narapidana teroris melalui deradikalisasi dan reintegrasi sosial untuk kembali ke masyarakat. Melalui wawancara beberapa mantan aktivis jihadis dan observasi program pemberdayaan, artikel ini berkesimpulan bahwa pelibatan mantan narapidana teroris di dalam upaya pemberdayaan sebagai program deradikalisasi alternatif dari pemerintah terhadap para eks napi teroris. Mereka bisa menjadi sebuah komunitas baru untuk para eks-ekstremis dalam mengungkapkan pandang dan keyakinan mereka secara terang-terangan. Kehadiran kelompok (mereka) ini menjadi aset penting dalam upaya mendorong narasi terhadap radikalisme dan terorisme di Indonesia.
\end{abstract}

Kata Kunci: Reintegrasi; Jihadis; Pembangunan Ekonomi, Indonesia. 
- SAIFUDIN ASRORI, AHMAD SYAUQI

\section{INTRODUCTION}

The involvement of former terrorist prisoners in social and economic empowerment efforts of ex-convicts who disengage the terrorist groups is an interesting and unique phenomenon. The empowerment efforts are based on the fact that many ex-convicts deal with an obstacle when 'returning' to the community. Some of them joined extremist groups and repeated acts of violence and terror. While other, spread radical and extreme ideological ideas, increased the distribution of radical groups. The participation of former terrorist inmates is important as part of government programs on eradicating terrorism in Indonesia.

Although leaving a terrorist group, due to various backgrounds and conditions. The process involves two important elements, push and pull factors. Related to push factors include, among others, hopes that involvement in terrorist groups will not be achieved, disappointment with the group, disappointment with individuals, difficulty adjusting to the group's style, inability to face the effects of terrorism, loss of faith in ideology, and boredom. Meanwhile, pull factors are structural factors such as divided loyalty, positive relationships with moderate groups, employment, and education opportunities, the desire to get married or build a family, financial incentives and amnesty.

The upsurge of violence and terrorism rooted in complex causes, which mostly affect individuals through group processes. Thus, an effort to pull out disengaged terrorists from radical groups, especially extremist groups that based on religious-minded is considered an act of disobedience to religious beliefs and apostasy. Leaving membership in extremist groups affected the loss of protection and the benefit of implementing religious teachings that will get the reward of 'eternity' in heaven.

This article, employ participant observation was given priority in field research to investigate the involvement of former terrorist prisoners in the social and economic empowerment of ex-convicts. Lamongan terrorist network gained international prominence after several of its residents were implicated in the 2002 and the 2005 Bali Bombing. Nowadays, this network became the group that attempted peace had an effort in the process of empowering exterrorist inmates. 


\section{METHOD}

This research uses a qualitative method with the type of research produces is descriptive data. The aim of qualitative research is to investigate meanings, interpretations, symbols, and the processes and relations of social life (Crossman, 2020). In addition, this study aims to accurately describe the characteristics of a particular individual, condition, symptom or group. By the method, it is intended to provide a broad picture of the involvement of former terrorist convicts in the government's deradicalization program.

There are several method in collecting qualitative data: direct observation, open-ended surveys, focus group, indepth interviews, oral history, participation observation, ethnographic observation, and content analysis. The research uses two methods: interviews and observations.

\section{RESULTS AND DISCUSSIONS}

\section{Government De-radicalization Program}

Rehabilitation and deradicalization of crimes of violence and terrorism began when the perpetrators were imprisoned. The Indonesian government mandates done based law number 5 of 2018 mandate the National Counterterrorism Agency (Badan Nasional Penanggulanggan Terorisme/BNPT) to take a certain way to to eliminate and or reduce exposure to violent ideologies.

Deradicalization process of mandated agency was concerning prevention, law enforcement and protection of victims with the soft approach strategies directed to provide influence on cognitive, motivational and social ex-convict. Cognitive aims to subdue the mind, change radical ideologies--correcting Islamic concepts: jihad, takfir, hakimmiyah, shahada and aligning objectives such as the Islamic state, and the khilafah, and how to change the ideology of violence and terror.

In the motivational aspect it aims to--soften the heart--to map the range of emotional upheavals: anger, frustration, complaints, humiliation, loss of selfmeaning, mapping various motivations: radical ideology, revenge, affection and love, thrill and status-seeking; Feelings of liking or disliking the deradicalization program, suffering while in detention. The social aspect aims at Social--reintegration into normal life--equipping a positive mental attitude as tolerance, mutual trust, cooperation, and equipping work skills.

The Indonesia model of guiding terrorism inmates according to Rabasa, 
(2010) is called the 'cultural approach', as the unification of the investigator's culture with prisoners, understanding their hopes and fears, and speaking the language. The approach is based on consideration when terrorists are arrested, very few terrorists want to talk. They will talk only to those they trust, and, in their minds, everyone who is connected with the government is their enemy. This model approach requires the police to treat prisoners humanely and develop bonds of trust. The intense approach taken by government officials and elements of society were able to reduce the potential for violence perpetrated by former Poso conflict jihadists. The process of de-radicalization which aims to relieve a radical ideology has conformity with the objectives of Indonesian correctional services, as social re-socialization and reintegration that implies change and group awareness to reshape attitudes and behavior inmate in relation to the community.

Jones's (2007) explains that ex-convicts of terrorism are spearheading changes in understanding within the environment of prisoners of terrorism. When prisoners are willing to accept assistance from the police and government agencies, it will be easy to open up to religious arguments by religious teachers whose credibility in the jihad movement. Schulze (2008) describes a positive change in the understanding of radicalism towards 170 prisoners of terrorism in Indonesian prisons who are following the de-radicalization program. The program has categorized targets consisting of former Afghan fighters, members of the Jama'ah Islamiyah, as well as individuals from social conflicts in Poso and Ambon. The de-radicalization program carried out needs to look at the relationships of each network and the typology of the actors.

Despite success stories, several studies assess the de-radicalization program as having weaknesses in achieving rehabilitation goals. According to Sukabdi (2015) The de-radicalization approach in Indonesia tends to focus on isolating prisoners involved in the de-radicalization program from other terrorist prisoners, providing practical incentives for prisoners to get involved, including holding them in better conditions and by providing economic assistance for themselves and their families, using former militants to debate current prisoners of ideology, reasons and justifications for violence, and organizing workshops to address issues such as anger management but also to develop practical skills for future work and provide new social relationships outside terrorist networks.

According to Andrie (2011) de-radicalization programs carried out and 
set independently by prison managers in accordance with the capabilities and capacities owned. Most of these prisons do not have special programs to rehabilitate or de-radicalize terrorist prisoners. The de-radicalization program in Indonesian prisons can be identified by several activities, such as providing conflict management training or inviting an Islamic cleric from the Indonesian Muslim Council (Majelis Ulama Indonesia/MUI) to deliver speeches and discussions with terrorist detainees. An interesting finding was that most participants refused to be involved in the program. These conditions have an impact on the effectiveness of the de-radicalization program.

\section{The Challenging of Indonesian De-radicalization}

The challenge of the efforts to de-radicalize former terrorist convicts lies in the argument that the violence used mostly appears in framing religiousminded. The involvement in radical groups and participation in violence is largely a manifestation of systems of thought and belief that develop in individuals or groups. This system of thought or ideology giving meaning to one's behavior and becomes a selection mechanism for complex choices. Ideology defines what is good and what is bad, what can be done and what should not be, what is morally right and what is wrong, who is a friend and who is an enemy, and so on.

There are several doctrines that have been reproduced by radical groups since the time of the Islamic State of Indonesia (Negara Islam Indonesia/NII); the doctrine of hijrah is the understanding that the basis of the Indonesian state is Pancasila. For this group, Pancasila is not an ideology, but merely a basic state that can be transformed into another ideology and basis, namely the basis of Islam. The goal is the creation of baldatun thaayyibun wa raabun ghafur or the Islamic State. Martyrdom or noble life. For the radical group to establish an Islamic state, it must reach self or family sacrifice. Islam is not only religion, but God's rules. This view must be applied to the whole system, rules of life and laws on earth.

A radical group as the mastermind behind the violence and terrorism in Indonesia Jama'ah Islamiyah (JI), JI Group is a confederation of several radical Islamic groups developing from Darul Islam led by Abu Bakar Ba'asyir and Abdullah Sungkar. the purpose of establishing JI was to listen to the Islamic Khilafah. The purification of the teachings of the Salaf al-Salih is done through the belief that only the Koran and the hadith are sources of reference for the 
behavior and thoughts of the Muslims. In how to understand religion, this group is characterized by a more literal and puritanical approach. One famous motto is "noble life or death gets heaven" (hidup mulai atau mati mendapat surga)". Through financial and logistical assistance transferred by al-Qaeda in Tanggara Asia, JI carried out various acts of terror and resistance in Indonesia.

Abuza's research on the radical group of Jama'ah Islamiyah (JI), identified several factors that motivated acts of terrorism: a strong desire to establish a khilafah system by undermining western-secular power aimed at implementing a holistic Islamic Sharia, the establishment of an Islamic state as a way of purification or purification of Islamic teachings, including cleansing of Western and secular values, the view that Islam is under attack by anti-Islamic forces, especially America and its allies and Christians, the view of a global conspiracy to weaken the power of Islam, as evidenced by the support of the global antiIslamic power to the separatists of Maluku and Timor Leste.

The terrorist group's argument is clearly seen in Noordin M. Top's accountability letter which reads: "We also declare that our enemy is the defender and helper of the salibi-judi alliance that controls the homeland of the Muslims namely the thoghut and apostate rulers of Indonesia who replaced the hudud of Allah with the punishment of pagan democracy and secular laws, which always intimidate, beat up, imprison and kill ulama and mujahideen." Resistance efforts are carried out through the doctrine of migrating to followers to forget the world, not caring about the family, leaving the parents, leaving the wife and children without leaving the cost of living. The meaning of Hijrah being taught makes a person frustrated living in the world, so he wants to die soon because he imagined the rewards of going to heaven.

The recognition of the Bali Bombers, Imam Samudra, was like a feeling of dissatisfaction and anger perceived in the frame in religious logic which then gave birth to a call of violence. Plainly. Ali Imron by showing how a number of mixed issues, ranging from disappointment to the government, calls for jihad, anger, and revenge, became a series of motives with religious dimensions that triggered brutal violence. For all of them, wherever the territory including Bali is also a battlefield for jihad, all non-Muslims and Westerners are legitimate enemies to be victims. Following are a number of reasons put forward; dissatisfaction with government. This is because the absence of Imamat (a leader who was appointed and appointed by Islamic standards or methods, such as the Caliph) 
has led to rampant disobedience and submission to non-Islamic leadership, Islamic Sharia is not implemented as a whole, hopes for the opening of jihad fi sabilillah, where a greater war will occur between Muslims against infidels after the Bali bombing, the bombing is a form of jihad obligation as instructed by religion, avenging the atrocities and oppression of the kuffar against Muslims as occurred in Palestine, Afghanistan, Chechnya, Somalia and a number of other countries. The bombing was also a form of revenge for Christians who fought with Muslims in Poso and Ambon.

A similar confession from a former JI official, Nasir Abbas, stated the reasons for leaving the terrorist group's network:

“... my exit from JI aims to save Muslims, to the extent of my ability, so as not to be affected by misconceptions, and so that Muslims in particular and humanity in general are not subject to bombings and attacks carried out without syar'i and humane reasons".

According to him the struggles of JI members who were mistaken in understanding jihad were no longer to eliminate the 'slander', but instead the struggle that gave rise to finah to the Muslims. Acts of terrorism carried out by JI members are formed by the understanding that Indonesia is in a state of war or darul-harb. In conditions of war, offensive jihad becomes open to all members, they are also permitted to seize state property and other people who are considered infidels (fa'i).

Abbas outlines some of the errors of JI teaching, disbelief of fellow Muslims. Disbelief always ends with hatred that leads to elimination or extermination. For this group, the blood and property of unbelievers is lawful. Fighting infidels or non-Muslims. The excessive hatred of JI members towards unbelievers is based on textual misunderstanding of the verses of the Qur'an. Examples of verses of the Qur'an that are always used by radical Muslim activists (command to kill and fight infidels), which means "...kill those idolaters wherever you find them". The command to kill all Americans and their allies from civil or military circles is an obligation for every Muslim which can be carried out in any country. Teachings may lie. This doctrine is related to the doctrine of al-Wala which is to help each other, love, defend and protect fellow members of the group and al-Barra that is hostile to anyone other than its members. In addition, there is an understanding that believes that the government is an enemy and believes Indonesia is darul harb, The teachings of the Hijrah by prioritizing worship by traveling for a long 
time rather than making a living for their families. In addition, avoiding getting involved with something related to the government including not studying in government schools, avoiding working in government and so forth.

The doctrine of open jihad can also be read also in the writings of Ustadz Abdurrahman, a radical figure who has power in the jihad movement in Indonesia today. Aman called on his followers to support ISIS and together with Ba'ashir declared the pledge of the caliphate of Abu Bakr al Bahgdadi. The foundation of jihad carried out by Aman Abdurrahman departs from the beliefs put forward by Indonesia with Islam. Actually, he has no doubts about the current state and government of Indonesia is a pagan state and a taghut government, so it must be agreed upon. The accusation of infidelity also applies to Muslims in this country who are aware of and follow the democratic system, are invited to vote, invited to sing the national anthem, and permit the foundation of the Pancasila state. The reasons for this jihadi figure stated that the Unitary Republic of Indonesia in pagan status were among others because: The law that is run is not God's law, Telling the case and the picture to the taghout. Thaghut approved is an international institution (such as the United Nations, International Court) whose legal source is not approved by Islam, The state and government (Indonesia) have loyalty to the infidels, such as America and European countries, and assist them in developing the mujahideen muwahhidin, Bring or reverse the right and authority to make laws and laws other than Allah, Granting the right to challenge shirk, disbelief and apostasy with religious freedom and human rights (Hak Asasi Manusia/HAM), Equating between infidels and Muslims, The system that runs is a democratic system and Homeland based on Pancasila.

In tadzkirah II. Abu Bakar Baasyir gave the bearers of office and power to want to leave the law of man-made infidels who can plunge them into disbelief and the threat of painful torture in the afterlife. In addition, the advice is also addressed to the Chair of the MPR/DPR and the state organizer who is concerned in the field of law and defense who claim that Muslims are no longer defending the pagan government system and the enforcement of ignorance laws before death fetches. If unable to repent with the above steps, then all leaders and members of the MPR/DPR must release their positions, as well as all the tagging officers in the field of law and defense must relinquish their posts in the taghag government, "Baasyir also asked their wives to advise their husbands to repent of relinquishing his position in the MPR / DPR and other agencies. If 


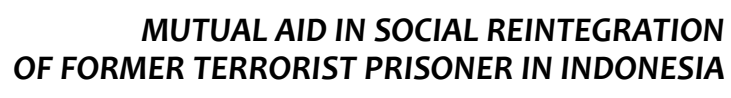

SAIFUDIN ASRORI, AHMAD SYAUQI

her husband refuses, his wife must go away from him because her marriage is canceled. Because according to him, their marriage was canceled because her husband was an infidel".

Some of these arguments, lead individuals or radical groups to the practice of violence aimed at the government and its apparatus called the taghut nation. It becomes very ironic indeed that in the end all acts of intolerance, persecution, violence and terror--including suicide bombing--in the eyes of this extreme group are considered as expressions of worship (worship) that will be rewarded glory to the perpetrators, namely the rewards of heaven. Even though most of the violence they have committed, with justification of religion is often haphazard, in fact it has damaged the message of majesty and glory that is the essence of Islamic teachings that prioritizes peace and safety for all humanity.

\section{Deradicalization Process of Former Terrorist Prisoner}

The existence of the Lamongan extremist group cannot be separated from the influence of the al-Islam pesantren in Tenggulun village, Solokuro subdistrict, Lamongan district. Tenggulun village is a remote village located in the middle of a dry rice field and fish ponds, banana trees and corn plants. Before entering the village there is a teak forest that lies on the edge of a dry field. The distance between Tenggulun village and Lamongan city is approximately 60 $\mathrm{Km}$. To reach the village one can use two-wheeled or four-wheeled vehicles, but there is no public transportation available. Public transportation only reaches the intersection of Paciran road to Solokuro District. Then in a distance of $10 \mathrm{KM}$ on an ojek, as well as from Solokuro Village (the capital of the sub-district) to Tenggulun Village, a distance of $7 \mathrm{Km}$.

The long story of the establishment of the al-Islam boarding school began with Grandfather Chozin, Chair of the al-Islam boarding school foundation having founded the Salaf boarding school during the Dutch occupation. Their family's ancestors were the ones who started the da'wah in this village. "Indeed, it is recognized by the people here that they can read bismilah, it can be fate from our ancestors," he said. After all this time the pesantren was present, a number of problems caused the cottage to begin to dim. The first problem was when Chozin's grandfather died while studying in Saudi Arabia. Finally the cottage ran out of cadres and gradually the first pesantren stopped. After a long vacuum, Chozin who had grown up was moved to immediately revive the 
pesantren that had been initiated by his ancestors. That hope was even more real when his younger brother Ali Gufron (Muchlas) graduated from Al Mukmin Ngruki Islamic Boarding School in 1985. However, in the same year Muchlas was mandated to serve in Afghanistan for five years. In 1990, Muchlas returned but did not go directly to Tenggulun. He returned to Malaysia and was married to a Malaysian woman by Uztadz Abu Bakar Baasyir and Ustadz Abdulah Sungkar. A year later, in 1991 Muchlas returned to Tenggulun to introduce his wife. He only lived for about a month and then left for Malaysia to start pioneering the Lukmanul Hakim Boarding School.

In Tenggulun, Chozin also began to pioneer al-Islam pesantren. Initially, Chozin consulted with the manager of Al Mukmin Ngruki about his desire to establish a pesantren in Tenggulun. "After seeing a lot of pesantren, there are only pesantren that in my opinion are only Al Mukmin Ngruki. We see the discipline of the students as well as the management discipline, " he said. Continuing in 1992 around July, he together with local Muhammadiyah leaders including his younger brother Jakfar Sodiq held a planning meeting to discuss the concept of pesantren. Only in 1993, al-Islam began teaching learning activities. This affiliation takes the form of the help of a teacher or instructor received by alIslam from al-Mukmin, Ngruki.

Like its parent pesantren, al-Islam pesantren aims to teach and practice the teachings of Islam in a kaffah. The process of indoctrination of jihad is carried out secretly and clandestinely. Some of the sources of the Jihad doctrine are books from Dr. Syeh. Abdullah Azzam, who is known to be one of the Salafi Jihadi ideologues, whose books teach a lot about the principles and application of pure Islam and kaffah Islam. The al-Islam pesantren also teaches military and war training, especially those taught by Islamic religious teachers / instructors who have been students and trainers in various mujahideen military academies, both Mindanao, Poso, Ambon and Afghanistan. The process of indoctrination of jihad was carried out by key radical figures, such as Ustad Abu Bakar Baa'syir. Meanwhile, jihad indoctrination from the Ustad Chozin family, after Ngruki was obtained in Malaysia, the Philippines, Thailand / Moro and Afghanistan. It is known that Ali Gufron, Ali Imron and Ali Fauzi are alumni of the Afghanistan Mujāhidīn Academy and Military Training Camp in Mindanao Philippines.

In addition to the closed and clandestine activities of the al-Islam pesantren, the success in instilling jihad indoctrination for its students was 


\section{MUTUAL AID IN SOCIAL REINTEGRATION \\ OF FORMER TERRORIST PRISONER IN INDONESIA}

SAIFUDIN ASRORI, AHMAD SYAUQI

also due to the apathetic nature of the villagers of Tenggulun. The population of Tenggulun Village is 2183 people. They mostly work as farmers, civil servants and private workers. Some residents work as overseas (Malaysia). Another social phenomenon that develops in Tenggulun Village is that, as a result of the large number of villagers who go to become migrant workers, divorce marriage in Tenggulun Village is common, especially if one who goes to work abroad is just one of a married couple. People who live or who leave to work, remarry in their respective places.

In subsequent periods, the development of radical ideology was able to develop rapidly in the Islamic Boarding School. This is also supported by the attitude of Tenggulun residents, the majority of whom are Nahdliyin (NU) residents, which is around 90\% (approximately 2263 people) and Muhammadiyah around 10\% (approximately 251 people) who tend to remain silent in letting all activities related to the existence of the Islamic Boarding School. Tenggulun community response to the establishment of Al Islam is quite diverse. The majority of Nahdiyin residents do not respond too much. "Yes, the people here are just stupid," Chozin said. Because it was founded by Muhammadiyah, the community considered that the main objective of Al-Islam was cadre. In the Muhammadiyah community itself there were pros and cons. Those who sympathize see Al Islam as an appropriate missionary endeavor. While those who contra assess if the characteristics of Al-Islam clothing is not appropriate. Although the Islamic Boarding School teaches aqidah which is different from the aqidah of most citizens, namely NU and Muhammadiyah. The same attitude was carried out by the Tenggulun Village Government apparatus. The condition had an impact on the involvement of al-Islam teachers and alumni in communal-religious conflicts in Ambon and Poso, and they made Poso a base for struggle and training centers.

The involvement of teachers and students in the area of conflict, attracting them to the Jama'ah Islamiyah network, through conditions that are not easy. They must follow the selection first, then bai'ah by the emir. Members are also not enough just to be Muslim. However, Islam with the flow of salafush sholih. After joining as members, they are subject to the obligation to defend and protect the emir, obey the rules, not do any acts of harm to the pilgrims and protect each other in all matters, especially regarding JI. They also have the right to prosperity, religious guidance and protection. Their financial 
resources to fund their programs are taken from infaq, zakat, and sodaqoh as well as sources that are considered halal. This other source is not haphazard, because JI only wants to accept it after there is ijtihad (discussion and debate of experts whether allowed or not). The pesantren al-Islam then became one of the pesanterns involved in the special operation unit of the Jama'ah Islamiyah (JI). Many JI bombing operations - the 2000 Christmas Eve bombings, attacks on the Philippine ambassador in Jakarta and the Bali bombings - are partly planned or started from al-Islam. As Ali Fauzi said, "This village has been tantrum because of the Bali bombing that was assembled in our house".

For this reason, it can be illustrated that the development of the Lamongan extremist group was built based on a number of interrelated relationships, namely the Al-Islam Pesantren Alumni Network and several pesantren affiliated to Jama'ah Islamiyah (JI); the strong commitment of the ideology of jihad as well as family and marriage. This group is not only a terrorist organization, they are a closed social community and strong network. the latest development is that the Lamongan extremist group has in recent years turned into a pro-ISIS sentiment. The footprint of an extremist network in Lamongan, East Java illustrates how support for local jihad resistance has been transformed into support for ISIS.

\section{Ex-Jihad Involvement In Deradicalization}

\section{Motivation for Change}

The groundbreaking of the renovation of the Baitul Muttaqin Mosque and the construction of the Al-Quran Education Park (TPA) in Solokuro, Lamongan on Wednesday, March 29, 2017 marks the commencement of the operation of the Circle of Peace Foundation. Founded Foundation aims to empower excombatants is expected to provide hope for ex-prisoner activists (napiteroris) to be empowered. As stated by its founder initiator, Ali Fauzi, "so far we have always been confused when a prisoner of terrorism came out of prison and confused about what to do. Finding a job is difficult, but there are children and wives who must be supported. YLP's presence is expected to provide a place for ex-terrorist inmates who provide support to their members with the same style but with different content. Upholding the values of peace, love, tolerance and preaching friendly Islam rather than anger. YLP actors are expected to be able to dedicate themselves to creating justice and peace through nonviolent means, operating at various distances from life-threatening conflicts, in various 


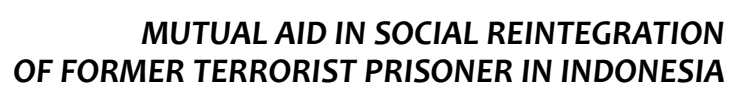

SAIFUDIN ASRORI, AHMAD SYAUQI

relationships with religious communities and official structures, and in some settings may look too bureaucratic, routine, or safe.

The urgency of empowerment carried out by YLP, at least based on two important reasons. First, the ability possessed by the napiter in using weapons, agitation and propaganda in the 'role field', and making bombs, has an impact on the barriers of employment that can accommodate. Secondly, the existence of a former terrorist stereotype makes it an obstacle for people to deal with them. The picture was as revealed by Sumarno (interview), “...we experienced a very bitter event, when no one approached..."

For this reason, it is important to empower former ex-combatants, Ali Fauzi, to feel called to be involved in empowerment efforts, "If no one wants to care, usually later they take action again", at least they are no longer involved in terrorist networks. This change also received support from BNPT, as expressed by the head of BNPT Suhardi was so happy when it was the former combatants who took the initiative. Without saying much, he immediately agreed to help and facilitate. "These are the most effective movements to suppress the pace of terrorism," he added. Suhardi revealed, currently there are a total of 1,500 terrorist inmates and around 560 who have just come out throughout 2016. What is encouraging, Suhardi added, only three terrorism inmates returned to carry out acts of terror.

Although some activists from the Lamongan extremist group have metamorphosed into groups oriented towards deradicalization and peace efforts, they are not free from internal and external pro and municipal dynamics of the group. Internal dynamics occur in connection with the al-Islam pesentren and Members of the JI Network. The dynamics in pesantren are illustrated in the interview with ust. Chozin Ali Fauzi, "there are still many friends who suspect our activities". As well as external groups, an interview from one of the local government employees revealed that:

"Because everything is controlled by the conspiracy theory, but we can only see the fact that today those who are terror activists initially now have turned into a process of deradicalization".

Apart from the dynamics of the pros and cons of the existence of YLP, it is hoped that this group will build a"new community', which can gradually oppose the extremist beliefs of their imprisoned families. Ali Fauzi revealed: 
"Important when they need us present. Only if it is too theorized is difficult. I have already profiled more than 40 friends and students myself, why did they come back? they joined the old group. this foundation as an alternative to creating a new community. Actually, there is a mutual taawun, but the contents are different. If they voice violence, we will be at peace. the method is the same. For example if they have a project in Yemen, yes we also go to Yemen, but the content is different. they like to go up our mountain too, but the contents are different. that's the most important. even more ideal if this foundation is supported by them, we can make it counter narrative, that's not there yet".

The Circle of Peace Foundation has identified about a dozen families who need economic support. If a family is having trouble finding school funding for their children, she helps them register with al-Islam for nothing. They also freely express their views on jihad without the need to be ostracized from their group, because they get reinforcement from friends of the community. In addition, individuals who are affiliated can express their aspirations, economic needs and prioritize their ideology without fear and anxiety.

\section{Empowerment Efforts}

\section{Collaboration between stakeholders}

The program that was first carried out by the Circle of Peace Foundation is to collaborate with stakeholders, where these stakeholders have a very large role in the development and continuation of efforts to empower ex-terrorist prisoners. If stakeholders can work well together, the continuation of deradicalization in Solokuro will be long-term. First, the role of al-Islam pesantren becomes very important in the continuity of this program, because this community is brought together for their attachment to al-Islam pesantren. Almost all of the exponents of the Circle of Peace Foundation have links to al-Islam, both as founding families, teachers and students. Support for the Lingkar Perdamian Foundation goes hand in hand with changes in the al-Islam pesantren. For the Islamic boarding school al-Islam, the involvement of religious teachers, students and alumni of the Islamic boarding school in the 2000 Christmas Eve Bombing and the 2002 Bali Bombing Case, truly became a turning point for changing the orientation of the pesantren, from jihad-dakwah-tarbiyah, became tarbiyah-da'wah-jihad. The efforts of Pesantren al-Islam in order to reduce radical understanding in the surrounding environment are carried out with acculturation with the 
surrounding environment, active in social activities such as School Committees and joining Muhammadiyah, forming Board of Caregivers and actively involved in de-radicalization activities.

Second, the local community of Tenggulun village and entrepreneurs have an active role in carrying out activities carried out by the Lingkar Perdamain Foundation. Tenggulun village itself is one of the remote villages in the Solokuro sub-district, Lamongan. The distance of this village from the City of Lamongan, East Java is approximately $60 \mathrm{Km}$. The population of Tenggulun Village is 2183 people, consisting of men and women. Tenggulun villagers mostly work as farmers, civil servants and private workers. Some residents work as overseas (Malaysia). Another social phenomenon that develops in Tenggulun Village is that, as a result of the large number of villagers who go to become migrant workers, divorce marriage in Tenggulun Village is common, especially if one who goes to work abroad is just one of a married couple. People who live or who leave to work, remarry in their respective places.

Third, collaboration with Local Government, Central, Police, Military and BNPT. As regulated in the legislation that acts of terrorism are a national problem, then the problem solving is taken care of by the central government through the National Anti-Terrorism Eradication Agency (BNPT). In designing the deradicalization program, the agency has four approaches, namely reeducation, rehabilitation, resocialization and reintegration. The government coordination will produce cooperation matters revealed in an interview with Ali Fauzi:

"Yes, maybe this time there is no funding. which is our mainstay, yes we have partners for our donors from friends of local entrepreneurs, also friends who have businesses in tenggulun, in the area of lamongan we are recruited to fund. If the funds from the previous government did not have funds to support the work program, maybe in 2018 we will only propose funds to the Lamongan regency because they also care for this foundation. Many of our friends have empowered us. There are many that we leave in the projects of fellow entrepreneurs".

In this effort the form of empowerment is carried out by the community, when government institutions and the community have not yet given a concrete form of empowerment. The results of an interview with Ali Fauzi revealed: "that acts of terror committed against jihadists are a criticism of the absence of the state". Many de-radicalization activities are the result of contributions from activists and contributions from sympathizers. 


\section{Social and Cultural Approach}

The approach taken by the Circle of Peace Foundation in deradicalisation efforts is divided into two, namely non-material, such as the change in the ideology of jihad from understanding jihad which is defined as fighting, killing, doing hard on the disbelievers, enemies of Islam into jihad in religious deeds. So, do not be surprised if old terrorists appear, because their doctrine is still strongly attached. Preventing them from using social media is hard work, especially now that it is a trend for young people. What can be done is to do enlightenment activities.

The indoctrication process is carried out through a fraternal approach through formal and non-formal institutions, through recycling, i'dad, rihlah, mukhoyyamah, and so forth. tasamuh / tolerance. The second is material, in the form of soft loans, capital loans, school fees for their children, health assistance, and so forth. Although the nature of material empowerment is still personal, private businesses exist. Capital finally exists, but step by step. Now how do we begin to build the perspective that peace is more beautiful. Provide therapy so they are not easily provoked. If you rely on funds from the government it usually focuses on the program. The success of building a new community is very dependent on non-material and material support, both of these support must be given simultaneously and cannot be separated.

Ali Fauzi, Chairperson of the Circle of Peace Foundation, said that terrorism is a problem that cannot be solved in only one way. "The roots of terrorism have been widely discussed by experts that the experts are not single, even interrelated, therefore the handling must also not be single, it must be many aspects, prefective and methodological", he said. In fact, Ali likens terrorism as an illness that is already in an alarming condition and needs more special handling. "Like a terrorist disease, there are complications that need specialists and peace campaigns from people who have contracted this disease. We have experienced this virus for years, but Alhamdulillah we can recover and get up and want to cure others", he explained.

Ali further said, for more severe challenges, because terrorism in Indonesia has been affected by global terrorism. "There are still many challenges ahead, considering that local terrorism is always influenced by global terrorism", he explained. Even so, Ali added, there needs to be prevention that must involve all components of society. "The community must be involved, community leaders, 
religious leaders, youth leaders, it is our duty together to unite the perspective, that terror is carried out by groups who want to shake the country", he explained.

Ex-Jihadist activists are non-violent religious militant groups which function among others according to Appleby as, "upholding religious traditions believed to be spiritual, theological insights and practices useful in preventing deadly conflicts or limiting their spread". Ex-Jihadist activists like antidotes for poisons of violence using religion. The transformation of the ex-maritime movement in the efforts to deradicalize terrorists or ex-terrorists contributes to the prevention of the return of maritime terrorist groups or organizations.

\section{CONCLUSION}

The involvement of ex-Jihadists in the effort to empower ex-terrorist prisoners (Napiters) as a concrete form in the deradicalization of terrorists in Indonesia. Through cooperation with various parties ex-Jihadists are proven able to establish friendships or relationships with groups outside the network of terrorist groups or moderate groups, becoming one of the individual factors or groups leaving violence and terror. Interwoven with outside groups is also useful for opening up jobs and capital. This group is the 'new community' for ex-extremists to express their views and beliefs without hiding. The presence of this group is a potential asset in promoting narratives against radicalism and terrorism in Indonesia.

\section{REFERENCE}

Altier, M.B., Boyle, E.L., Shortland, N.D., \& Horgan, J.G. (2017). "Why they leave: An analysis of terrorist disengagement events from eighty-seven autobiographical accounts". Security Studies, 26(2), 305-332.

Appleby, S.R. (1999). The ambivalence of the sacred: Religion, violence, and reconciliation. England: Rowman \& Littlefield Publishers.

Ashour, 0. (2009). The de-radicalization of Jihadists: Transforming armed Islamist movements. New York: Routledge.

McCauley, C., \& Moskalenko, S. (2013). "Two Possible Profiles of Lone-actor Terrorists". This report represents the views and opinions of the contributing authors. The report does not represent official USG policy or position.

Moghaddam, F.M. (2005). "The staircase to terrorism: A psychological exploration". American psychologist, 60(2), Feb-Mar 2005, 161-169. 
- SAIFUDIN ASRORI, AHMAD SYAUQI

Barrelle, K. (2015). "Pro-integration: disengagement from and life after extremism". Behavioral sciences of terrorism and political aggression, 7(2), 129-142.

Berntzen, L.E., \& Sandberg, S. (2014). "The collective nature of lone wolf terrorism: Anders Behring Breivik and the anti-Islamic social movement". Terrorism and Political Violence, 26(5), 759-779.

Bjorge, T., \& Horgan, J. (eds.). (2009). Leaving Terrorism Behind: Individual and Collective Disengagement. New York: Routledge

Bjorgo, T., \& Bjørgo, T. (2013). Strategies for preventing terrorism. Springer.

Chalmers, I. (2017). “Countering Violent Extremism in Indonesia: Bringing Back the Jihadists". Asian Studies Review, 41(3), 331-351.

Charles, T. (1978). From Mobilization to Revolution. Reading, Addison-Wesley Publishing.

Crenshaw, M. (1992). "Current research on terrorism: The academic perspective". Studies in Conflict \& Terrorism, 15(1), 1-11.

Crossman, Ashley. (2020, August 28). "An Overview of Qualitative Research Methods". Retrieved from https://www.thoughtco.com/qualitativeresearch-methods-3026555

Moghaddam, F.M., \& Marsella, A.J. (2004). "Understanding terrorism: Psychosocial roots, consequences, and interventions". American Psychological Association.

Harris-Hogan, S. (2017). Violent Extremism in Australia: An overview. Trends and Issues in Crime and Criminal Justice, 491: 1.

Horgan, J. (2008). Deradicalization or Disengagement? A Process in Need of Clarity and a Counterterrorism Initiative in Need of Evaluation. Perspectives on Terrorism, 2(4), 3-8.

Wirawan, J. (2018, 18 Mei). Serangan Bom Surabaya: Program Deradikalisasi Dinilai Gagal, BNPT Tak Menerima. Retrieved from https://www.bbc.com/ indonesia/indonesia-44154828

Hwang, J. C. (2018). Why Terrorists Quit: The Disengagement of Indonesian Jihadists. Cornell University Press.

Hwang, J.C., Panggabean, R., and Fauzi, I.A., (2013). The Disengagement of Jihadis in Poso, Indonesia. Asian Survey 53(4), 754-777.

Jacobson, M. (2010). Terrorist dropouts: Learning from those who have left (Policy Focus, 101). Washington: The Washington Institute for Near East 


\section{Policy, 75}

Lentini, P. (2008). Understanding and Combating Terrorism: Definitions, Origins and Strategies. Australian Political Studies Association, 43(1), 133-140.

Lipset, S. M., \& Raab, E. (1970). The politics of unreason: right wing extremism in America, 1790-1970 (Vol. 5). New York: Harper \& Row,

Lutz, J. M., \& Lutz, B. J. (2005). Terrorism: Origins and Evolution. New York: Palgrave Macmillan.

Rabasa, A., Pettyjohn, S. L., Ghez, J. J., \& Boucek, C. (2010). Deradicalizing Islamist Extremists. RAND Corp Arlington VA National Security Research Div.

Schmid, A. P. (Ed.). (2011b). The Routledge Handbook of Terrorism Research. New York: Routledge.

Silber, M. D., Bhatt, A., \& Analysts, S. I. (2007). Radicalization in the West: The homegrown threat (pp. 1-90). New York: Police Department.

Tambiah, S. J. (1996). Ethnonationalist conflicts and collective violence in South Asia. University of California Press. 